\title{
Valorization of dietary lemon pomace waste to enhance lucerne silage composition and quality characteristics, and ruminal biogas production and fermentation
}

\section{Maghsoud Besharati}

Tabriz University: University of Tabriz

Valiollah Palangi ( $\square$ valiollah.palangi12@ogr.atauni.edu.tr)

Ataturk Universitesi https://orcid.org/0000-0001-6470-2608

\section{Zabihollah Nemati}

Tabriz University: University of Tabriz

\section{Rashid Safari}

Tabriz University: University of Tabriz

\section{Abdelfattah Z. M. Salem}

Universidad Tecnológica de México - Campus Toluca: Universidad Tecnologica de Mexico - Campus Toluca

\section{Research Article}

Keywords: Ddegradability, Silage, waste sour Lemon pomace, lucerne, environmental pollution

Posted Date: April 5th, 2021

DOl: https://doi.org/10.21203/rs.3.rs-392203/v1

License: (c) (1) This work is licensed under a Creative Commons Attribution 4.0 International License. Read Full License 


\section{Abstract}

The purpose of this study was to investigate the effect of adding various levels of waste sour lemon pomace to lucerne on the properties and ruminal gas production of silage. Levels of 0 (Control), 25 (L1), 50 (L2), 75 (L3), and 100 (L4) \% lemon pomace were replaced by lucerne for silage preparation and silenced for 60 days. The experiment was conducted in a completely randomized design with three replications (3 silos per treatment). After opening the silos, $\mathrm{pH}$ and dry matter were measured immediately, and the dried samples were kept at -20 until further tests. The silage $\mathrm{pH}$ decreased with the addition of lemon pomace compared to the control $(p<0.05)$. Total silage volatile fatty acids and dry matter content increased with adding lemon pomace. The results of gas production also showed that lemon pomace increased the in vitro gas production volume. Adding lemon pomace to lucerne silage due to the high pectin content in these agricultural wastes caused a rapid decrease of silage pH and an acidic environment. It prevented the growth of non-beneficial bacterial species. The obtained data showed that waste sour lemon has a good potential to use as a livestock feedstuff that can be useful in reducing the cost of ruminant production and preventing environmental pollution.

\section{Statement Of Novelty}

Ruminal microorganisms allow ruminants to utilize human's unusable biomass and convert non-protein nitrogen into microbial protein to obtain energy and amino acids. This capability has led them to convert low biological value feeds into high-value products. The use of agricultural waste in the diet of ruminants can be important in reducing production costs and avoiding the accumulation of large amounts of agricultural waste that can pose environmental risks. In this experiment, it was tried to evaluate a by-product such as lemon pomace waste as animal feedstuff in the preparation of silage, which plays a role in reducing environmental pollution and reduces the cost of animal ration.

\section{Introduction}

Forage is an important component of the ruminant ration, which the leguminous family is of great importance, and from this family, lucerne is more important. Identifying the quality and nutritional value of forage plants because of their importance in animal nutrition can effectively describe animal nutrition. In the meantime, the lucerne plant is of particular importance as a queen of forage crops and also because of its good quality, palatability, and availability of nutrients, including minerals, proteins, and vitamins, especially vitamin $\mathrm{A}[1,2]$.

Silages are popular and useful components of ration in modern dairy operations [3]. Accordingly, making silage common and wide-spreading in humid regions, where lucerne (Medicago sativa L.) has been widely cultivated in the developed animal farming [3]. Nevertheless, it is challenging to improve Lucerne silage quality because of the lack of efficient fermentation. Several additives have been used to modify silage fermentation by increasing lactic acid production [4]. Lucerne as forage for silage is included the following problems, lack of water-soluble carbohydrates, high buffering capacity [5], vulnerability to Clostridia under adverse fermentation conditions [6], empty stem, and low dry matter. From about 30 to 40 years ago, carbohydrate and bacterial additive sources have been studied to improve silage quality.

Citrus pomace [7-9], tomato pomace [10,11], apple pomace [12,13], sugarcane pomace [14, 15], and pistachio hulls [16] residues are among the by-products of the conversion and agricultural industries that are identified as potential sources for livestock feed. These materials are produced in the respective plants depending on the season of fruit production and are largely discarded without any use causing environmental pollution. Given that carbohydrate sources can stimulate fermentation but cannot prevent proteolysis, as a result, due to heterolactic fermentation, it leads to a decrease in $\mathrm{pH}$ [17]. Sour lemon pomace as an agricultural by-product, improper disposal of that can cause environmental pollution. Besides, it can be used in the diet to reduce the cost of nutrition [18]. Otherwise, the skin and seeds of lemons contain essential oils that can prevent the growth of some harmful microorganisms in the ensilage process, and also in the fermentation process, it can prevent the loss of energy by some organisms in the form of methane and increase fermentation efficiency.

Therefore, the simultaneous use of microbial additives and a suitable source of carbohydrates in silage can produce better fermentation and higher nutritional value. Air-drying is applied to optimize the dry matter content of the forage before silage. Very

Page $2 / 12$ 
low dry matter silage is often associated with an increase in effluent production and Clostridium fermentation. In contrast, high dry matter silage is not well compressed and greatly reduces aerobic stability. The optimal dry matter for lucerne silage depends on the type of silage structure, environmental and management conditions [4]. Adding lemon pomace to lucerne silage because of the high pectin content in these agricultural wastes can rapidly reduce silage $\mathrm{pH}$ and create an acidic environment, thus preventing the growth and proliferation of non-beneficial bacteria species. The purpose of this study was to investigate the effects of adding waste sour lemon pomace on the properties, composition, and degradability of lab-scale lucerne silage.

\section{Materials And Methods}

\section{Feeds and Treatments}

The whole second cut lucerne (at the flowering stage) was harvested at $25 \mathrm{DM}$ and wilted for $24 \mathrm{~h}$ at comfortable ambient temperature. The wilted lucerne and sour lemon pomace were chopped manually to nearly $2-3 \mathrm{~cm}$ length cut. The treatments were: L0; lucerne (control), L25; 75\% lucerne with 25\% lemon pomace, L50; 50\% lucerne with 50\% lemon pomace, L75; 25\% lucerne with $75 \%$ lemon pomace, and L100; $100 \%$ lemon pomace. Trial samples were ensiled in laboratory silos for $60 \mathrm{~d}$ at room temperature $\left(17\right.$ to $\left.20^{\circ} \mathrm{C}\right)$.

At the end of 60 days ensiling, silos were opened, and immediately $\mathrm{pH}$ and $\mathrm{DM}$ were measured. The remaining samples were stored in the refrigerated room at $-20^{\circ} \mathrm{C}$ for subsequent analysis. Acid detergent fiber NDF contents were determined with the method described by Van Soest et al. [19] without sodium sulfite, Crude ash, and crude protein (CP) contents of the resultant silages were measured according to AOAC [20]. The concentration of VFA of silages was calculated by using Besharati et al. [21] procedure.

Hydrous sap was collected from ensiled samples by mixing $20 \mathrm{~g}$ of silage with $180 \mathrm{~mL}$ of deionized water and uniforming this mix for 1 min. And silage $\mathrm{pH}$ was specified using a pH meter. NH3-N concentration of acidified silage saps was determined using the distillation method. The phenol sulfuric acid method was used to measure water-soluble carbohydrates [22]. The distillation method described by Besharati et al. [23] was used to measure total VFA in silage. One ml of $25 \%$ meta-phosphoric acid ( $\mathrm{v} / \mathrm{w}$ ) was added to $5 \mathrm{ml}$ of filtered extract to determine VFA. For the measurement of lactic acid, the Borshchevskaya et al. [24] method was used.

Fleigh points (FP) was calculated according to Lashkari et al. [25] with the following equation: FP $=220+[(2 \times \%$ DM) -15$]-[40$ $\times \mathrm{pH}$. Silage quality is characterized as following very good (85-100), good (60-85), moderate (55-60), satisfying (25-55) and bad quality/worthless (<25).

\section{Enumeration Of Microorganisms}

The microbial population was enumerated according to Lashkari et al. [25] method. The cultivation environment of lactic acid bacteria (LAB) and total bacteria (TB) were MRS agar and NA agar. Yeasts and molds were identified by using SDA agar [25].

\section{In Vitro biogas production Test}

The in vitro biogas production value of experimental samples was measured in serum bottles using Palangi et al. [7] method. The rumen fluid required for the determination of in vitro GP parameters was provided from newly slaughtered animals. GP was measured in each vial after $2,4,8,12,16,24,36,48,72,96$, and $120 \mathrm{~h}$ of incubation using a water displacement apparatus [7, 21].

In a separate run of GP completed on silage samples, the method of Besharati et al. $[2,26]$ was adopted to determine the dry matter degradability. The DM truly degraded $(\mathrm{mg})$ amounts at incubation times were measured [27]. Distillation continued until about $50 \mathrm{ml}$ of distilled material was collected in the collection tank. Then the solution was titrated with $0.1 \mathrm{~N}$ sulfuric acid [26]. The prepared samples were stored at $-20^{\circ} \mathrm{C}$. Before analysis, the samples were incubated at room temperature overnight to melt frozen samples [26].

\section{Mathematical Modeling with MATLAB ${ }^{\circledR}$}


An optimization method combining the MATLAB curve fitting toolbox and the numerical algorithm based on the LevenbergMarquardt way was used. The models were identified through the editor toolstript, and the starting points and ranges required for the models were defined. We used the goodness of fit measure function to measure the error values of the fit curves in studied models [28].

Models I and II are Simple negative exponential curve models (monomolecular, Mitscherlich, or first-order kinetics model) without and with a lag phase [29]. Model III is Gompertz curve, asymmetrical about an inflection point $\mathrm{M}$, calculated from $\mathrm{K}=\exp (\mathrm{cM}$ ) [30]. Model IV is Generalised Mitscherlich, generalization of the model I (results in the model I for $d=0$ ), with the addition of a square root time dependence component [31].

\section{Statistical Analysis}

The experiment results were analyzed by one-way analysis of variance by GLM procedure, and the Duncan test compared treatment means [32].

\section{Results And Discussion}

\section{Effect of lemon pomace on chemical composition of silage}

This experiment showed that adding a carbohydrate source such as lemon pomace to lucerne silage decreased the silage $\mathrm{pH}$ linearly compared to the control treatment $(p<0.05)$. The amount of dry matter affected by lemon pomace increased linearly $(p<$ 0.05). Total VFA increased linearly in treated lucerne hay silage with lemon pomace compared to control treatment $(p<0.05)$ (Table 1).

Table 1

Effects of lemon pomace on the chemical composition of lucerne silage after $60 \mathrm{~d}$ ensiling

\begin{tabular}{|llllll|}
\hline Treatment & pH & DM & Ash & Total VFA & Fleigh point \\
\hline Control & $5.85^{\mathrm{a}}$ & $16.35^{\mathrm{b}}$ & 8.95 & $4.50^{\mathrm{b}}$ & $37.7^{\mathrm{d}}$ \\
\hline L1 & $5.18^{\mathrm{b}}$ & $17.80^{\mathrm{b}}$ & 8.82 & $9.33^{\mathrm{a}}$ & $33.4^{\mathrm{d}}$ \\
\hline L2 & $4.30^{\mathrm{c}}$ & $22.29^{\mathrm{a}}$ & 7.52 & $8.66^{\mathrm{a}}$ & $77.58^{\mathrm{c}}$ \\
\hline L3 & $3.61^{\mathrm{d}}$ & $23.96^{\mathrm{a}}$ & 9.05 & $7.33^{\mathrm{ab}}$ & $108.52^{\mathrm{b}}$ \\
\hline L4 & $3.39^{\mathrm{d}}$ & $25.16^{\mathrm{a}}$ & 9.94 & $6.33^{\mathrm{ab}}$ & $119.72^{\mathrm{a}}$ \\
\hline SEM & 0.19 & 1.08 & 1.94 & 1.1 & 2.32 \\
\hline Trt. & $<.0001$ & $<.0001$ & 0.1397 & $<.0001$ & 0.0107 \\
\hline Linear & $<.0001$ & $<.0001$ & 0.1457 & 0.0005 & 0.0576 \\
\hline Quadratic & $<.0001$ & $<.0001$ & 0.3021 & $<.0001$ & 0.3422 \\
\hline Cubic & $<.0001$ & $<.0001$ & 0.3021 & $<.0001$ & 0.3422 \\
\hline Differ & & $<.001$ & \\
\hline
\end{tabular}

Differences between the averages indicated by different letters in the same column are important

Control: lucerne hay; L1: 75\%lucerne + 25\% lemon pomace; L2: 50\%lucerne + 50\% lemon pomace; L3: 25\% lucerne + 75\%lemon pomace; L4: lemon pomace

SEM: Standard Error Mean

Results of this study have corresponded with the results of Hashemzadeh-Cigari et al. [33], Karimi [34], Gozelpour [35], and Abdollahzadeh et al. [36], who have examined the different carbohydrate sources on forage silages. In an experiment conducted by Hashemzadeh-Cigari et al. [37] using carbohydrate sources such as barley, sucrose, and apple pomace on lucerne silage, all the 
treated silages had good quality, and the control group had a moderate rate. The $\mathrm{pH}$ of all groups was similar and low, while the highest $\mathrm{pH}$ and the lowest amount of lactic acid were observed in the control group. And the reason for this depends on the amount of organic acid produced during the fermentation process. The use of a carbohydrate source in the silage decreased the $\mathrm{pH}$ and increased lactic acid concentration. But it did not affect ammonia nitrogen. They stated that when making lucerne silage as one of the hard-to-store plants for storage, a rapid carbohydrate source should be added.

In the experiments of Hashemzadeh-Cigari et al. [37], molasses to lucerne hay increased the total amount of VFA. In a similar experiment using different apple pomace levels in silage, they reported an increase in total VFA [35]. Abdullahzadeh et al. [36] also reported a rise in total VFA by adding tomato pomace and apple pomace to silage compared to the control treatment, which was similar to this experiment. The addition of molasses to lucerne silage in Hashemzadeh-Cigari et al. [37]'s experiment also increased the total VFA.

\section{Effect of lemon pomace on in vitro biogas production parameters}

The addition of lemon pomace to the lucerne silage caused a significant increase with the control treatment during the incubation times $(p<0.05)$. According to the results, the highest amount of biogas production was related to lemon pomace without lucern (L4), and the lowest amount of biogas production was related to control treatment at all incubation times.

The results (Table 2 and Fig. 1) show that the amount of lemon pomace significantly affects biogas production. As seen in the L3 treatment, by adding $75 \%$ lemon pomace, biogas production linearly increases. On the other hand, there was decreasing in biogas production by reducing lemon pomace (L2). The fitted models for in vitro degradability of lucerne silage based on the coefficient of determination (r2) showed that because of high R2 and Adjusted R amounts, all of the models were fitting the best to lucerne silage (Table 3).

Table 2

Effects of experimental treatments on in vitro gas production capability

\begin{tabular}{|c|c|c|c|c|c|c|c|c|c|c|c|}
\hline \multirow[t]{2}{*}{ Treatment } & \multicolumn{11}{|c|}{ Incubation times (h) } \\
\hline & 2 & 4 & 6 & 8 & 12 & 16 & 24 & 36 & 48 & 72 & 96 \\
\hline Control & $9.48^{\mathrm{e}}$ & $12.88^{e}$ & $17.74^{\mathrm{e}}$ & $23.71^{e}$ & $28.04^{\mathrm{e}}$ & $30.87^{e}$ & $40.43^{e}$ & $54.75^{\mathrm{e}}$ & $64.43^{\mathrm{e}}$ & $98.81^{d}$ & $112.25^{d}$ \\
\hline L1 & $12.48^{d}$ & $16.13^{d}$ & $21.54^{d}$ & $28.39^{d}$ & $32.60^{d}$ & $35.06^{d}$ & $48.91^{d}$ & $69.89^{d}$ & $82.96^{\mathrm{d}}$ & $103.46^{c}$ & $112.90^{d}$ \\
\hline L2 & $16.37^{c}$ & $20.57^{c}$ & $26.20^{c}$ & $34.82^{c}$ & $41.15^{c}$ & $43.82^{c}$ & $59.12^{c}$ & $86.09^{c}$ & $99.83^{\mathrm{C}}$ & $120.89^{b}$ & $130.99^{b}$ \\
\hline L3 & $22.91^{\mathrm{b}}$ & $27.49^{b}$ & $33.84^{b}$ & $44.29^{b}$ & $51.53^{b}$ & $54.66^{b}$ & $70.44^{b}$ & $97.77^{b}$ & $105.23^{b}$ & $122.90^{\mathrm{b}}$ & $126.03^{\mathrm{C}}$ \\
\hline L4 & $26.47^{a}$ & $32.04^{a}$ & $39.28^{a}$ & $50.40^{\mathrm{a}}$ & $58.97^{a}$ & $62.65^{a}$ & $74.55^{\mathrm{a}}$ & $102.32^{\mathrm{a}}$ & $118.44^{\mathrm{a}}$ & $155.54^{\mathrm{a}}$ & $175.98^{\mathrm{a}}$ \\
\hline SEM & 0.3 & 0.26 & 0.36 & 0.56 & 0.52 & 0.62 & 0.76 & 0.72 & 1.18 & 0.66 & 1.01 \\
\hline \multicolumn{12}{|c|}{ Differences between the averages indicated by different letters in the same column are important } \\
\hline \multicolumn{12}{|c|}{$\begin{array}{l}\text { Control: lucerne; L1: } 75 \% \text { lucerne + 25\% lemon pomace; L2: } 50 \% \text { lucerne + } 50 \% \text { lemon pomace; L3: } 25 \% \text { lucerne + } 75 \% \text { lemon } \\
\text { pomace; L4: lemon pomace }\end{array}$} \\
\hline \multicolumn{12}{|c|}{ SEM: Standard Error Mean } \\
\hline
\end{tabular}


Table 3

Estimated gas production parameters of Lucerne silage using different mathematical models with MATLAB

Prameter $^{1}$

$\begin{array}{llllllllll}\text { a } & \text { b } & \text { c } & \text { L } & \text { d } & k & S_{S E}^{2} & \text { R-Square } & \text { Adj R-Square } & \text { Iter }\end{array}$

Control

\begin{tabular}{lllllllllll} 
Model I & 8.91 & 242.7 & 0.0059 & - & - & - & 84.23 & 0.9929 & 0.9911 & 7 \\
\hline Model II & 118.2 & 133.3 & 0.0059 & 0.5989 & - & - & 84.23 & 0.9929 & 0.9899 & 23 \\
\hline Model III & -203.7 & 178.9 & 0.0119 & - & - & 0.4316 & 83.50 & 0.9930 & 0.9900 & 103 \\
\hline Model IV & 95.5 & 276.5 & 0.0028 & 75.07 & -0.0116 & - & 79.38 & 0.9933 & 0.9889 & 40
\end{tabular}

L1

\begin{tabular}{lllllllllll} 
Model I & 8.15 & 134.0 & 0.0165 & - & - & - & 54.29 & 0.9957 & 0.9946 & 12 \\
\hline Model II & 63.63 & 78.55 & 0.0165 & 0.5343 & - & - & 54.29 & 0.9957 & 0.9939 & 7 \\
\hline Model III & -53.97 & 112.8 & 0.0309 & - & - & 0.247 & 39.18 & 0.9969 & 0.9956 & 14 \\
\hline Model IV & 35.86 & 141.9 & 0.0167 & 14.48 & 0.0321 & - & 48.46 & 0.9962 & 0.9936 & 5
\end{tabular}

L2

$\begin{array}{lllllllllll}\text { Model I } & 10.4 & 146.2 & 0.019 & - & - & - & 84.01 & 0.9950 & 0.9938 & 5 \\ \text { Model II } & 70.76 & 85.8 & 0.019 & 0.5327 & - & - & 84.01 & 0.9950 & 0.9929 & 12 \\ \text { Model III } & -57.49 & 125.9 & 0.034 & - & - & 0.2443 & 61.00 & 0.9964 & 0.9948 & 14 \\ \text { Model IV } & 56.75 & 144.5 & 0.018 & 20.47 & 0.0442 & - & 72.49 & 0.9957 & 0.9928 & 6\end{array}$

L3

\begin{tabular}{|llllllllllll} 
Model I & 15.69 & 120.9 & 0.028 & - & - & - & 102.98 & 0.9929 & 0.9911 & 5 \\
\hline Model II & 60.81 & 75.83 & 0.028 & 0.147 & - & - & 102.98 & 0.9929 & 0.9899 & 18 \\
\hline Model III & -80.19 & 111.9 & 0.041 & - & - & 0.3491 & 88.31 & 0.9939 & 0.9913 & 24 \\
\hline Model IV & 80.5 & 88.4 & 0.025 & 27.3 & 0.0644 & - & 91.73 & 0.9937 & 0.9895 & 16 \\
\hline L4 & & & & & & & & & & & \\
\hline Model I & 24.59 & 229.4 & 0.011 & - & - & - & 118.16 & 0.9953 & 0.9942 & 6 \\
\hline Model II & 119.5 & 134.5 & 0.011 & 0.5339 & - & - & 118.16 & 0.9953 & 0.9933 & 17 \\
\hline Model III & -336.1 & 204.0 & 0.164 & - & - & 0.5500 & 123.07 & 0.9951 & 0.9931 & 109 \\
\hline Model IV & 17.3 & 169.0 & 0.008 & 0.1859 & -0.0444 & - & 99.25 & 0.9961 & 0.9935 & 5
\end{tabular}

${ }^{1} a=$ rapidly soluble fraction (\%); $b=$ slowly degradable fraction (\%); $c=$ degradation rate constant (\%/h) of fraction 'b'; $L=$ lag time (h); $d=$ is the parameter pertaining to the variable fractional rate of degradation; $k=$ slope, or degradation rate coefficient $\left(\mathrm{h}^{-1}\right)$;

${ }^{2} \mathrm{SSE}=$ Sum of Squares Due to Error; R-Square = the square of the correlation between the response values and the predicted response values; Adj R-Square = Degrees of Freedom Adjusted R-Square; Iter = iteration number of MATLAB.

${ }^{3}$ Model I, First-order kinetics model without lag phase; Model II, First-order kinetics model with lag phase; Model III, Gompertz model; Model IV, Generalised Mitscherlich model. 
Based on the results of the gas's capability in this experiment, in the investigations of Hashemzadeh-Cigari et al. [37] that measure the effect of different carbohydrate sources on silage, there was also an increase in biogas production in the experimental treatment compared to the control. Besharati et al. [38] investigated the effects of some by-products using in vitro biogas production, and reported that the highest volume of biogas produced was from apple pomace, which may be due to the high levels of non-starch carbohydrates and pectin. In the experiment of Khattoni et al. [39] that evaluated different carbohydrate sources, the results showed that pomace treatments had the highest volume of biogas produced at all incubation times. Ghorbani [40] reported the effect of levels of 50,100 , and $150 \mathrm{mg} / \mathrm{kg}$ orange essence on 256-day-old corn silage biogas production, as an increase in biogas production in the second treatment compared to the control $(p<0.01)$.

\section{The effect of lemon pomace on the in vitro dry matter degradability}

The addition of lemon pomace to the lucerne silage increased linearly in vitro biodegradability (from $2 \mathrm{~h}$ to $24 \mathrm{~h}$ ) compared to the control group ( $\mathrm{<}<0.05$; Table 4). This can be explained by the higher soluble carbohydrate content and higher acidic insoluble fiber in the treatment. At 12 hours after incubation, the highest disappearance was observed in L4 treatment (55.25\%) and the lowest in lucerne silage without additive (35.42\%). At 24 hours after incubation, the highest amount was related to L4 (68.25\%), and the lowest amount was to the control group (52.40\%).

Table 4

Effect of lemon pomace on Lucerne silage dry matter biodegradability by in vitro method

\begin{tabular}{|c|c|c|c|c|c|}
\hline \multirow[t]{2}{*}{ Treatment } & \multicolumn{5}{|c|}{ Incubation time } \\
\hline & 2 & 4 & 8 & 12 & 24 \\
\hline Control & $13.21^{d}$ & $15.42^{d}$ & $22.45^{\mathrm{d}}$ & $35.42^{d}$ & $52.40^{d}$ \\
\hline L1 & $18.35^{c}$ & $21.30^{c}$ & $39.35^{c}$ & $43.75^{\mathrm{c}}$ & $62.01^{c}$ \\
\hline L2 & $21.18^{b}$ & $26.18^{b}$ & $40.02^{b}$ & $50.18^{b}$ & $65.11^{b}$ \\
\hline L3 & $22.88^{b}$ & $28.88^{b}$ & $41.88^{b}$ & $50.40^{\mathrm{b}}$ & $65.09^{b}$ \\
\hline L4 & $24.05^{\mathrm{a}}$ & $31.35^{a}$ & $44.25^{\mathrm{a}}$ & $55.25^{\mathrm{a}}$ & $68.25^{\mathrm{a}}$ \\
\hline SEM & 0.140 & 0.562 & 0.911 & 1.101 & 1.222 \\
\hline \multicolumn{6}{|c|}{$\begin{array}{l}\text { Control: Iucerne; L1: } 75 \% \text { lucerne + } 25 \% \text { lemon pomace; L2: } 50 \% \text { lucerne + } 50 \% \text { lemon pomace; L3: } 25 \% \text { lucerne + } 75 \% \text { lemon } \\
\text { pomace; L4: lemon pomace }\end{array}$} \\
\hline \multicolumn{6}{|c|}{ SEM: Standard Error Mean } \\
\hline
\end{tabular}


Table 5

Effect of treatments on in vitro N-NH3 and VFA

\begin{tabular}{|c|c|c|c|c|}
\hline \multirow[t]{2}{*}{ Treatment } & \multicolumn{2}{|c|}{$\begin{array}{l}\text { VFA } \\
(\mathrm{mmol} / \mathrm{L})\end{array}$} & \multicolumn{2}{|l|}{$\begin{array}{l}\mathrm{N}-\mathrm{NH}_{3} \\
(\mathrm{mmol} / \mathrm{L})\end{array}$} \\
\hline & $12 \mathrm{~h}$ & $24 \mathrm{~h}$ & $12 \mathrm{~h}$ & $24 \mathrm{~h}$ \\
\hline Control & $61.35^{d}$ & $69.12^{d}$ & $114.83^{b}$ & $421.15^{a}$ \\
\hline L1 & $67.55^{d}$ & $116.10^{c}$ & $147.00^{\mathrm{ab}}$ & $203.00^{c}$ \\
\hline L2 & $89.10^{c}$ & $109.05^{c}$ & $99.17^{c}$ & $137.66^{d}$ \\
\hline L3 & $105.30^{b}$ & $125.66^{b}$ & $136.50^{a b}$ & $383.83^{b}$ \\
\hline L4 & $126.59^{a}$ & $145.10^{a}$ & $127.33^{b}$ & $379.19^{b}$ \\
\hline SEM & 1.346 & 0.843 & 11.451 & 7.332 \\
\hline P-Value & $<.0001$ & $<.005$ & $<.0001$ & $<.0001$ \\
\hline Trt. & $<.0001$ & $<.005$ & $<.0001$ & $<.0001$ \\
\hline Linear & $<.0001$ & 0.0561 & $<.0001$ & $<.0001$ \\
\hline Quadratic & $<.0001$ & $<.0001$ & 0.004 & $<.0001$ \\
\hline Cubic & $<.0001$ & $<.0001$ & 0.004 & $<.0001$ \\
\hline \multicolumn{5}{|c|}{ Means within same column with different superscripts differ $(P<0.05)$. } \\
\hline \multicolumn{5}{|c|}{$\begin{array}{l}\text { Control: lucerne; L1: } 75 \% \text { lucerne + } 25 \% \text { lemon pomace; L2: } 50 \% \text { lucerne + 50\% lemon pomace; L3: } 25 \% \text { lucerne + } 75 \% \text { lemon } \\
\text { pomace; L4: lemon pomace }\end{array}$} \\
\hline \multicolumn{5}{|c|}{ SEM: Standard Error Mean } \\
\hline
\end{tabular}


Table 6

Effect of lemon pomace on microbial population of silage

\begin{tabular}{|c|c|c|c|}
\hline Treatment & Yeasts and Moulds $\left(\log 10^{4}\right)$ & Lactobacillus bacteria $\left(\log 10^{5}\right)$ & Total bacteria $\left(\log 10^{6}\right)$ \\
\hline Control & $2.87^{d}$ & $3.00^{d}$ & $3.13^{e}$ \\
\hline L1 & $2.93^{d}$ & $3.22^{c}$ & $3.61^{d}$ \\
\hline L2 & $3.30^{c}$ & $3.24^{c}$ & $3.87^{c}$ \\
\hline L3 & $4.10^{\mathrm{b}}$ & $3.74^{\mathrm{b}}$ & $4.08^{b}$ \\
\hline L4 & $4.42^{\mathrm{a}}$ & $4.11^{\mathrm{a}}$ & $4.24^{\mathrm{a}}$ \\
\hline SEM & 0.04 & 0.01 & 0.04 \\
\hline Trt. & $<.0001$ & $<.0001$ & $<.0001$ \\
\hline Linear & $<.0001$ & 0.3951 & $<.0001$ \\
\hline Quadratic & $<.0001$ & $<.0001$ & $<.0001$ \\
\hline Cubic & $<.0001$ & $<.0001$ & $<.0001$ \\
\hline \multicolumn{4}{|c|}{ Differences between the averages indicated by different letters in the same column are important } \\
\hline \multicolumn{4}{|c|}{$\begin{array}{l}\text { Control: lucerne hay; L1: } 75 \% \text { lucerne + } 25 \% \text { lemon pomace; L2: } 50 \% \text { lucerne + 50\% lemon pomace; L3: } 25 \% \text { lucerne }+75 \% \text { lemon } \\
\text { pomace; L4: lemon pomace }\end{array}$} \\
\hline \multicolumn{4}{|c|}{ SEM: Standard Error Mean } \\
\hline
\end{tabular}

The addition of lemon pomace significantly reduced NH3-N compared to the control. Rodrigues et al. [41] observed a significant decrease in ammonia nitrogen by adding levels of 1,2, and 2 percent apple pulp to straw, which is consistent with the present experiment's findings. The microbial population was increased in the treatments treated lemon pomace additive compared to the control, which may be due to alternative energy sources for microbial usage. Since lucerne silage contains a large amount of ammonia nitrogen, its synchronization with a soluble carbohydrate source can optimize microbial protein production and fermentation products obtained from microbial metabolism activities. Since adding orange, pomace decreases the amount of silage protein. It increases the carbohydrate ratio in the silage and since the amount of biogas produced in protein fermentation is lower than carbohydrates. This may also be another explanation for the increase in biogas production in the group containing lemon pomace.

\section{Conclusion}

This study showed that sour lemon pomace could be used in high quantities as an additive to lucern silage and livestock feedstuff, thereby improving environmental conditions. Adding lemon pomace to lucerne silage decreased the silage $\mathrm{pH}$ compared to the control treatment and increased in vitro biogas production and biodegradability. In general, it can be concluded that the use of a carbohydrate source as a useful source for bacterial populations on high-quality lucerne silage improved lucern silage quality and is necessary due to the deficiencies of this valuable plant.

\section{Declarations}

\section{Conflict of interest declaration}

The authors declare no conflict of interest.

\section{Abbreviations}


ADF: acid detergent insoluble fiber; BGP:biogas production; CP:crude protein; DM:dry matter; EE:ether extract; FP:Fleigh points GP:biogas production; IVGP:in vitro biogas production; LAB:Iactic acid bacteria; NDF:neutral detergent fiber; OM:organic matter; TB:total bacteria; VFA:volatile fatty acids.

\section{References}

1. Palangi, V., Macit M.: Indictable mitigation of methane emission using some organic acids as additives towards a cleaner ecosystem. Waste Biomass Valori. (2021). https://doi.org/10.1007/s12649-021-01347-8

2. Besharati, M., Palangi, V., Niazifar, M., Nemati, Z.: Comparison study of flaxseed, cinnamon and lemon seed essential oils additives on quality and fermentation characteristics of lucerne silage. Acta Agric. Slovenica. 115(2), 455-462. (2020). https://doi.org/10.14720/aas.2020.115.2.1483

3. Yuan, X.J., Li, J.F., Dong, Z.H., Shao, T.: The reconstitution mechanism of napier grass microiota during the ensiling of alfalfa and their contributions to fermentation quality of silage. Bioresour. Technol. 297, 122391. (2020). https://doi.org/10.1016/j.biortech.2019.122391

4. Muck, R.E., Nadeau, E.M.G., McAllister, T.A., Contreras-Govea, F.E., Santos, M.C., Kung, J.L.: Silage review: recent advances and future uses of silage additives. J. Dairy Sci. 101(5), 3980-4000. (2018). https://doi.org/10.3168/jds.2017-13839

5. Coblentz, W.K., Muck, R.E.: Effects of natural and simulated rainfall on indicators of ensilability and nutritive value for wilting alfalfa forages sampled before preservation as silage. J. Dairy Sci. 95(11), 6635-6653. (2012). https://doi.org/10.3168/jds.2012-5672

6. Muck, R.E., Kung, L.: Silage production. Pages 617-633 in Forages: The Science of Grassland Agriculture. 6th ed. II. Blackwell Publishing. Ames, IA, USA pp. 617-633. (2007).

7. Eivazi, P., Palangi, V., Jalili, M., Dadgar, N., Eslampeivand, A.: Protein degradation kinetics of treated and untreated by-products by using nylon bags. Eur. J. Exp. Biol. 2 (3):850-852. (2012).

8. Tayengwa, T., Chikwanha, O.C., Gouws, P., Dugan, M.E.R., Mutsvangwa, T., Mapiyea, C.: Dietary citrus pulp and grape pomace as potential natural preservatives for extending beef shelf life. Meat Sci. 162, 108029. (2020). https://doi.org/10.1016/j.meatsci.2019.108029

9. Lee, Y.H., Ahmadi, F., Kim, Y.I., Oh, Y.K., Kwak, W.S.: Co-ensiling garlic stalk with citrus pulp improves the fermentation quality and feed-nutritional value. Asian-Austral. J. Anim. Sci. 33(3), 436-445. (2020). https://doi.org/10.5713/ajas.19.0464

10. Rahbarpour, A., Palangi, V., Eivazi, P., Jalili, M.: Calculation of metabolizable protein and energy of tomato pomace by nylon bags and gas production data. Eur. J. Exp. Biol. 2, 822-825. (2012).

11. Buffa, G., Tsiplakou, E., Mitsiopoulou, C., Pulina, G., Nudda, A.: Supplementation of by-products from grape, tomato and myrtle affects antioxidant status of dairy ewes and milk fatty acid profile. J. Anim. Physiol. Anim. Nut. 104, 493-506. (2019). https://doi.org/10.1111/jpn.13315

12. Maslovarić, M.D., Vukmirović, Đ., Pezo, L., Čolović, R., Jovanović, R., Spasevski, N., Tolimir, N.: Influence of apple pomace inclusion on then process of animal feed pelleting. Food Addit. Contam. Part A. 34(8), 1353-1363. (2017). https://doi.org/10.1080/19440049.2017.1303851

13. Alarcon-Rojo, A.D., Lucero, V., Carrillo-Lopez, L., Janacua, H.: Use of apple pomace in animal feed as an antioxidant of meat. S. Afr. J. Anim. Sci. 49 (1), 131-139. (2019). https://doi.org/10.4314/sajas.v49i1.15

14. Gado, H.M., Elghandour, M.M.Y., Cipriano, M., Odongo, N.E., Salem, A.Z.M.: Rumen degradation and nutritive utilization of wheat straw, corn stalks and sugarcane bagasse ensiled with multienzymes. J. Appl. Anim. Res. 45(1), 485-489. (2017). https://doi.org/10.1080/09712119.2016.1217866

15. Kermani, M.M.M., Bahrololoum, S., Koohzadi, F.: Investigating the possibility of producing animal feed from sugarcane bagasse using oyster mushrooms: a case in rural entrepreneurship. J. Global Ent. Res. 9(52), 1-8. (2019). https://doi.org/10.1186/s40497-019-0174-2

16. Yurtseven, S., Kaya, Z., Takim, K.: The effect of pomegranate peel and pistachio hulls on performance and enteric methane emissions in straw-fed lambs (ovis aries I.). Appl. Ecol. Environ. Res. 17(1), 305-316. (2019).

http://doi.org/10.15666/aeer/1701_305316

Page $10 / 12$ 
17. Aksu, T., Baytok, E., Karslı, M.A., Muruz, H.: Efects of formic acid, molasses and inioculant additives on corn silage composition, organic matter digestibity and microbial protein synthsis in ship. Small Ruminant Res. 61, 29-33. (2006). https://doi.org/10.1016/j.smallrumres.2004.12.013

18. Palangi, V., Taghizadeh, A., Sadeghzadeh, M.K.: Determine of nutritive value of dried citrus pulp various using in situ and gas production techniques. J. Biodivers. Environ. Sci. 3(6), 8-16. (2013).

19. Van Soest, P.J., Robertson, J.B., Lewis, B.A.: Methods for dietary fiber, neutral detergent fiber, and non-starch polysaccharides in relation to animal nutrition. J. Dairy Sci. 74, 3583-3597. (1991). https://doi.org/10.3168/jds.S0022-0302(91)78551-2

20. AOAC: Official Methods of Analysis of AOAC International, 17th ed. Official Methods of Analysis, Gaithersburg, MD, USA. (2000).

21. Besharati, M., Palangi, V., Moaddab, M., Nemati, Z., Pliego, A.B., Salem, A.Z.M.: Inluence of cinnamon essential oil and monensin on ruminal biogas kinetics of waste pomegranate seeds as a biofriendly agriculture environment. Waste Biomass Valori. https://doi.org/10.1007/s12649-020-01167-2

22. Besharati, M., Abdi, E.: Effect of adding polyethylene glycol and polyvinyl pyrrolidon on in vitro gas production of pomegranate seed. J. Agric. Nat. Resour. 20(2), 128-132. (2017). https://doi.org/10.18016/ksujns.42109

23. Besharati, M., Shafipour, N., Abdi, E., Nemati, Z.: Effects of supplementation alfalfa silage with molasses, orange pulp and Lactobacillus buchneri on in vitro dry matter digestibility and gas production. J. Biosci. Biotechnol. 6(1), 43-47. (2017).

24. Borshchevskaya, L.N., Gordeeva, T.L., Kalinina, A.N., Sineokii, S.P.: Spectrophotometric determination of lactic acid. J. Anal. Chem. 71, 755-758. (2016). https://doi.org/10.1134/S1061934816080037

25. Lashkari, S., Taghizadeh, A., Seifdavati, J., Salem, A.Z.M.: Qualitative characteristics, microbial populations and nutritive values of orange pulp ensiled with nitrogen supplementation. Slovak J. Anim. Sci. 47(2), 90-99. (2014).

26. Besharati, M., Nemati, Z., Safari, R.: The effect of adding whey and L. Buchneri to alfalfa silage on in vitro gas production and degradability. Anim. Prod. Sci. 10(26), 56-63. (2019).

27. Taghizadeh, A., Safamehr, A., Palangi, V., Mehmannavaz, Y.: The determination of metabolizable protein of some feedstuffs used in ruminant. Res. J. Biol. Sci. 3, 804-806. (2008).

28. Palangi, V., Macit, M.: In situ crude protein and dry matter ruminal degradability of heat-treated barley. Revue Méd. Vét. 170, 123-128 (2019).

29. Ørskov, E.R., McDonald, I.: The estimation of protein degrability in the rumen from incubation measurements weighted according to rate of passge. J. Agric. Sci. 92(2), 499-503 (1979). https://doi.org/10.1017/S0021859600063048

30. France, J., Thornley, J.H.M., Lopez, S., Siddons, R.C., Dhanoa, M.S., Van Soest, P.J., Gill, M.: On the two-compartment model for estimating extent of feed degradation in the rumen. J. Theor. Biol. 146, 269- 287. (1990). https://doi.org/10.1016/S00225193(05)80139-0

31. Dhanoa, M.S., France, J., Siddons, R.C., Lopez, S., Buchanan, S.J.G.: A non-linear compartmental model to describe for age degradation kinetics during incubation in polyester bags in the rumen. British J. Nut. 73, 3-15. (1995). https://doi.org/10.1079/BJN19950004

32. SAS: Institute Inc. SAS/CONNECT ${ }^{\circledR} 9.4$ User's Guide. Fourth Edition. Cary. NC: SAS Institute Inc. (2018).

33. Hashemzadeh-Cigari, F., Khorvash, M., Ghorbani, G.R., Taghizadeh, A.: The effects of wilting, molasses and inoculants on the fermentation quality and nutritive value of lucerne silage. S. Afr. J. Anim. Sci. 41, 377-388. (2011). https://doi.org/10.4314/sajas.v41i4.8

34. Karimi, M.: Influence of Lactic Acid Bacteria on Properties, Compounds and Laboratory Biodegradation of Alfalfa Silage and Orange Pomace. Master of Science in Animal Sciences. Faculty of Agriculture, Tabriz University. Iran. (2016).

35. Gozlepour, V.: The Effect of Herbal Essential Oil Supplementation on the Characteristics, Compounds and Laboratory Biodegradability of Silage Alfalfa Silage with Different Levels of Apple Pulp. Master of Science in Animal Sciences. Faculty of Agriculture, Tabriz University. Iran. (2017).

36. Abdollahzadeh, F., Pirmohammadi, R., Fatehi, F.: Effect of feeding ensiled mixed tomato and apple pomace on performance of Holstein dairy cows. Slovak J. Anim. Sci. 43(1), 31- 35. (2010). 
37. Hashemzadeh-Cigari, F., Khorvash, M., Ghorbani, G.R., Ghasemi, E., Taghizadeh, A., Kargar, S., Yang, W.Z.: Interactive effects of molasses by homofermentative and heterofermentative inoculants on fermentation quality, nitrogen fractionation, nutritive value and aerobic stability of wilted alfalfa (Medicago sativa L) silage. J. Anim. Physiol. Anim. Nut. 98, 290-299. (2014). https://doi.org/10.1111/jpn.12079

38. Besharati, M., Taghizadeh, A., Janmohammadi, H., Moghadam, G.: Evaluation of some by-Products using in situ and in vitro Gas Production Techniques. American J. Anim. Vet. Sci. 3(1), 7-12. (2008).

39. Khatooni, M.A., Nobar, R.S., Cheraghi, H.: Evaluating possibility replacement of by-product of apple pomace with barley grain for ruminants by in vitro gas production technique. J. Anim. Sci. Adv. 4(5), 839-844. (2014).

40. Gorbani, H.: The effect of different amounts of essential oil of peppermint and fennel on the chemical composition and parameters of corn silage gas production in vitro. 6th Iranian Congress of Animal Science. Tabriz University. Iran. (2014).

41. Rodrigues, G. H., Susin, I., Pires, A. V., Mendes, C. Q., Araujo, R. C. D., Packer, I. U., Gerage, L. V.: Replacement of corn by citrus pulp in high grain diets fed to feedlot lambs. Ciênc. Rural. 38(3), 789-794. (2008). http://dx.doi.org/10.1590/S010384782008000300031

\section{Figures}

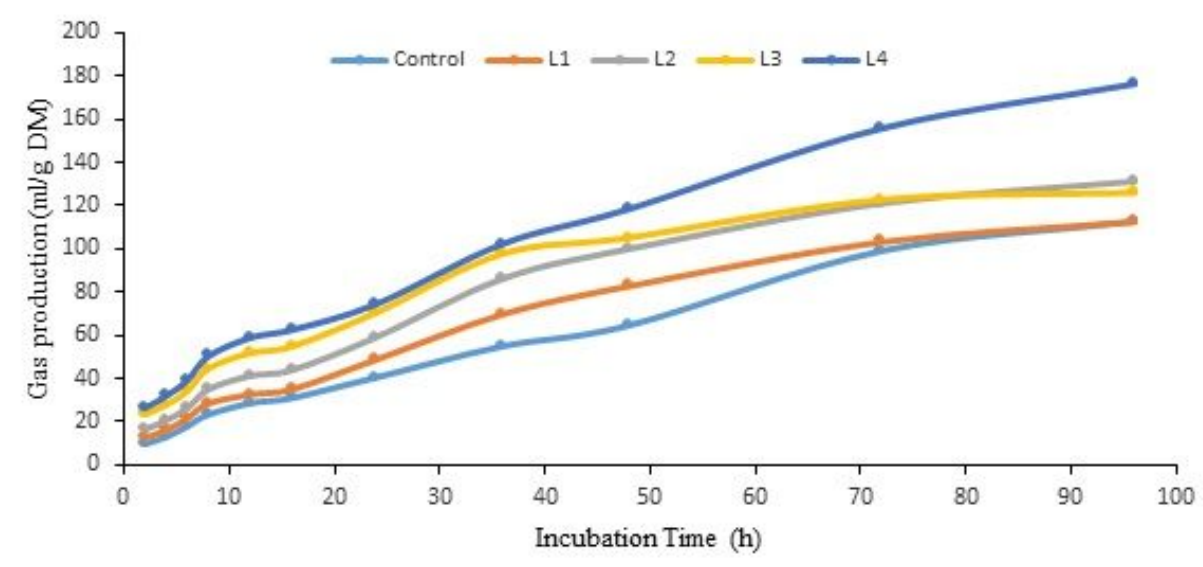

\section{Figure 1}

Effect of adding lemon pomace to silage on biogas production. Control: lucerne; L1: 75\%lucerne + 25\% lemon pulp; L2: $50 \%$ lucerne $+50 \%$ lemon pomace; L3: $25 \%$ lucerne $+75 \%$ lemon pomace; L4: lemon pomace

\section{Supplementary Files}

This is a list of supplementary files associated with this preprint. Click to download.

- GraphicalAbstract.jpg 